\title{
SPOLEČENSKÁ ODPOVĚDNOST FIREM V KONTEXTU ROZVOJE SOCIÁLNÍCH SLUŽEB V ČESKÉ REPUBLICE
}

\author{
Lucie Kamrádová, Jana Žáčková
}

\section{Klíčová slova:}

společenská odpovědnost firem, sociální služby, střednědobé (komunitní) plánování

\section{Key words:}

Social corporate responsibility, social services, medium-term (community) planning

\begin{abstract}
Abstrakt
Článek se zabývá stručným rozborem procesu stř̌ednědobého plánování rozvoje sociálních služeb v obcích a regionech v České republice ve vztahu k možnostem prezentace firemní filantropie a angažovanosti firmy ve smyslu společensky odpovědné organizace. Obsah příspěvku částečně uvádí do terminologie, která se váže jak k problematice plánování sociálních služeb, tak i k problematice společenské odpovědnosti firem. Cílem příspěvku bylo poukázat na nabízející se a stále ne př́iliš využívanou možnost provázanosti a partnerství sociálních služeb a soukromých firem, v souvislosti se současným trendem realizace společenské odpovědnosti firem.
\end{abstract}

\begin{abstract}
The article gives a brief analysis of medium-term planning process of development of social services in municipalities and regions in the Czech Republic in relation to the possibilities of presentation of company philanthropy and commitment to the company in sense of socially responsible organization. The article presents terminology that connects both, the issue of social services planning, as well as the issue of corporate social responsibility. The aim of this paper was to point out the obvious and still not too much used option of interconnection and partnership of social services and private companies in connection to the current trend of implementation of corporate social responsibility.
\end{abstract}

\section{Úvod}

Hovoříme-li o problematice společenské odpovědnosti, hned na počátku si musíme uvědomit, že za touto aktivitou či spíše iniciativou stojí vlastníci a majitelé daných podniků popř́padě jejich vrcholový management. Zaměstnanci podniků se pak mohou na základě popudu nadřízených těchto aktivit účastnit. Vlastní podnět $\mathrm{k}$ aktivitě tvoří tedy jakási podniková kultura společnosti nebo konkrétně podnikatelská etika vlastníků. Koncept společenské odpovědnosti firem nabízí celou řadu atributů pro oblast rozvoje sociálních služeb, avšak sociální služby a poskytovatelé sociálních služeb možností dostatečně nevyužívají. Obsah článku nastiňuje prostor $\mathrm{v}$ němž se sociální služby a společenská odpovědnost firem střetávají.

\section{Kontext sociálních služeb}

Sociální služby v České republice prošly od 90. let minulého století v rámci reformy sociální politiky rozsáhlou transformací. Dle Potůčka ${ }^{1}$ je jedním $\mathrm{z}$ cílů reformy sociální politiky po roce 1989 pluralizace sektoru sociálních a zdravotních služeb a aktérů vstupujících do arény sociální politiky. Socialistická éra odkázala občanům České republiky velmi chudé spektrum

\footnotetext{
${ }^{1}$ POTƯČEK, M. Křižovatky české sociální reformy. Praha: SLON, 1999.
} 
služeb, především těch, které usilují o podporu sociálního začleňování v přirozené komunitě občana ${ }^{2}$. Průša dokonce tvrdí, že ,,systém sociálního zabezpečení, který byl u nás prakticky až do poloviny 90 . let minulého století stále v platnosti, byl ve svých základních principech $\mathrm{v}$ řadě případi̊ koncipován ve 2 . polovině 50 . let, tedy v době, kdy existovaly zcela jiné představy o řízení společensko-ekonomických procesư‘‘3. Je tedy zcela nasnadě, že změny v společensko-politických poměrech musely nastartovat soustavu reforem v celé sociální oblasti. V současnosti po takřka dvaceti létech musíme konstatovat, že dědictví socialistické éry ještě nebylo zcela překonáno, a to z několika zřejmých důvodů. Tyto důvody mohou být jak ekonomické (materiální), tak sociálně-psychologické povahy.

Realizátoři sociálních služeb se neustále potýkají s různými problémy, z nichž jedna oblast zahrnuje nedostatečné množství materiálních zdrojů a financí, i když okruh donátorů se $\mathrm{v}$ posledních dvou desetiletích rozšsiríil. V tomto směru lze spatřovat první rovinu možností, které právě koncept společenské odpovědnosti firem rozvoji sociálních služeb v regionech nabízí. Druhou rovinu, která je v tomto příspěvku označena jako sociálně-psychologická, lze vymezit jako stále vysokou míru očekávání ze strany obyvatel vůči zabezpečovací funkci státu a malou míru vlastní zodpovědnosti. Princip subsidiarity, tedy přenos kompetencí a především odpovědnosti na nižší úroveň ve věcech saturace sociálních potřeb obyvatel tak stále není zcela naplněn. Zodpovědnost státu a jeho orgánů jako hlavního subjektu sociální politiky vůči občanům je v sociálním státě neoddiskutovatelná. Vláda a správní orgány státu zodpovídají za realizaci konkrétní sociální politiky v dané zemi ve spolupráci s ministerstvem, krajskými úřady, ale především obcemi a místními komunitami a institucemi i občanskými iniciativami ${ }^{4}$. Avšak míra začlenění jednotlivých elementů občanské společnosti do sociální politiky se odvíjí v prvé řadě od určitých historických a sociálně-psychologických podmínek. Tyto jsou v České republice stále do značné míry poznamenány předchozím socialistickým obdobím. Jak ve své studii uvádí Aidukai ${ }^{5}$ Česká republika patří k zemím tzv. východního bloku, kde je občanská společnost a potažmo tedy i míra participace občanů na věcech veřejných stále nízká. I v této rovině lze najít styčnou plochu mezi praktickou realizací sociální odpovědnosti firem a procesem plánování rozvoje sociálních služeb v krajích a obcích.

V České republice bylo soukromé podnikání během socialistické éry potlačeno, takže prostor pro jakoukoliv podporu firem v rámci sociálních služeb a sociálního podnikání nebylo prakticky možné. Přestože se v posledních letech objevila kritika společenské odpovědnosti firem ve prospěch nových a údajně mnohem lepších způsobů vnímání podnikatelského a společenského rozhraní, často je mezi těmito koncepty obtížné najít hranici a mnohdy se jedná pouze o modifikaci samotného konceptu společenské odpovědnosti. V návaznosti na výše uvedené skutečnosti je rostoucí potenciál $\mathrm{CSR}^{6}$ zřejmý už z pozice toho, že se v posledních letech společenská odpovědnost firem netýká jen firem, ale také neziskových organizací, akademické půdy, státního sektoru či samostatné vlády ${ }^{7}$.

\footnotetext{
${ }^{2}$ MICHALÍK, J. Smluvní vztahy v sociálních službách. Olomouc: VCIZP, 2008, s. 32-33.

${ }^{3}$ PRŮŠA, L. Sociální služby - srovnání ČR a EU, Praha: Centrum sociálních služeb, 2008, s. 7.

${ }^{4}$ KREBS, V. a kol. Sociální politika. Praha: ASPI, 2007.

${ }^{5}$ AIDUKAI, J. Old welfare state theories and new welfare regimes in Eastern Europe: Challenges and implications. In Communist and Post-Communist Studies, issue 1, vol. 42, 2009, p. 36.

${ }^{6}$ Společenská odpovědnost firem [online] Byznys pro společnost. Fórum odpovědných firem, c2010.

${ }^{7}$ KULDOVÁ, L. Společenská odpovědnost firem. Etické podnikání a sociální odpovědnost v praxi. Plzeň: OPS, 2010, s 18.
} 


\section{Koncept sociální odpovědnosti firem}

Sociální odpovědnost firem se stala takřka fenoménem dnešní doby. Avšak spojitost mezi tímto konceptem a sociálním systémem je patrná už z historie. Můžeme poukázat na to, že první zmínky o nutnosti odpovědného chování firem datujeme k polovině 20. století a samotný koncept CSR je starý jako podnikání samo. Firmy od počátku svého vzniku řeší problém, zda se věnovat čistě vlastnímu prospěchu či zájmu ostatních lidí a celé společnosti. I v historii rozvoje podnikání by se našli filantropicky orientovaní jednotlivci i skupiny podnikatelů, kteří se pokusili zmírnit neblahé sociální dopady ekonomických krizí u existenčně ohrožených skupin obyvatelstva. Koncept společenské odpovědnost firem se dynamicky vyvíjí již několik desetiletí. Za jednoho z prvních teoretiků tohoto konceptu je považován H. R. Bown, který ve své knize Social Responsibilities of the Businessman interpretoval CSR jako závazky podnikatele uskutečňovat takové postupy, prrijímat taková rozhodnutí nebo následovat takové směry jednání, které jsou z hlediska cílů a hodnot naší společnosti žádoucîi ${ }^{8}$ Existuje mnoho definic společenské odpovědnosti firem, žádnou z nich však nelze považovat za univerzální. Jedním z důvodů může být skutečnost, že není jednotně definována zákonem ani normami, proto si jednotlivý autoři a odborníci tuto problematiku definují rozdílně, přesto však ve své podstatě všichni vystihují totéž. Pomineme-li definice vytvořené Evropskou unií a mezinárodní organizací Business for Social Responsibility, můžeme za stěžejní pro tento př́íspěvek považovat definování společenské odpovědnosti jako kontinuálního závazku podniků chovat se eticky a přispívat k ekonomicky udržitelnému růstu a zároveň se zasazovat o zlepšení kvality života zaměstnanců, jejich rodin a stejně tak lokální komunity a společnosti jako celku ${ }^{9}$. Tato charakteristika vytvořená dle zásad a vizí World Busines Council for Sustainable Development v roce 2009 nepoukazuje jen na problematiku společenské odpovědnosti firem, ale také na téma udržitelného rozvoje ${ }^{10}$, což je jednou ze stěžejních oblastí zájmu nejen problematiky CSR, ale také oblasti komunitního plánování rozvoje měst a sociálních služeb. ${ }^{11}$ Problematikou společenské odpovědnosti firem se zabývá také evropská komise ve své zelené knize, nicméně skutečnost, že není tento směr zakotven a přesně vymezen v legislativě, se v dnešní době jeví jako nedostatek. Záleží pouze na daném ekonomickém subjektu, zda se rozhodne do komunity, v jejímž regionu působí, investovat kapitál nebo se jakýmkoliv způsobem angažovat pro dobro ostatních.

Společenskou odpovědnost firem můžeme rozdělit do tří základních sfér oblasti působení. Je to sféra ekonomická, environmentální a sociální. Každá z těchto sfér má svá specifika a charakteristické rysy i oblasti působení.

\section{Graf 1: Jednotlivé části Společenské odpovědnosti firem}
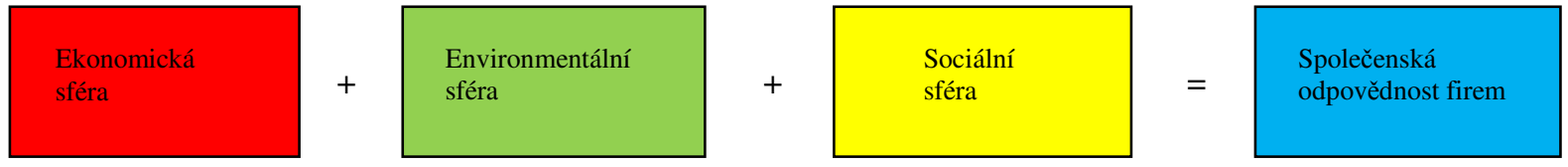

Zdroj: Vlastní zpracování

Ekonomická sféra zahrnuje v rámci společenské odpovědnosti shodu na požadavcích, které se vztahují k principům řízení a kontroly organizace, akce proti úplatkářství, uplatnění platební

\footnotetext{
${ }^{8}$ KUNZ, V. Společenská odpovědnost firem. Praha: Grada, 2012, s. 15.

${ }^{9}$ Corporate Social Responsibility [online] World Business Council for Sustainable Development, c2012.

${ }^{10}$ About the Rio +20 Conference. [online] United Nations Conference on Suustainable Development, c2011.

${ }^{11}$ KUNZ, V. Společenská odpovědnost firem. Praha: Grada, 2012, s. 23.
} 
morálky, dodržování smluv, plnění závazků a ochraně spotřebitele. ${ }^{12}$ Environmentální sféra se zabývá mimo jiné ochranou životního prostředí, investicemi do ekologických technologií, úsporami energie, ekologickou politikou podniku a organizace. ${ }^{13}$ Sociální sféra společenské odpovědnosti firem je charakterizována jako jedna z hlavních přínosů společnosti. Patří sem firemní filantropie a firemní dobrovolnictví, podpora vzdělávání, ochrana ohrožených skupin obyvatelstva, sponzorství a dobrovolnictví.

\section{Sociální sféra CSR - rovina konkrétní aplikace v sociálních službách}

Sektor služeb je značně rozsáhlý a představuje celou škálu nejrůznějších činností od jednoduchých procesů až k nejsložitějším operacím. V oblasti sociálních služeb vyvíjí aktivity různé typy organizací, jednotlivci, menší organizace a firmy i nadnárodní společnosti mající jak ziskový tak neziskový charakter. Sociální služba jak uvádí např́íklad Molek ${ }^{14}$, je činností nebo souborem aktivit, jejímž cílem je pomoci člověku řešit jeho nepříznivou sociální situaci. Zákon ${ }^{15}$ považuje sociální službu za činnost zajištující pomoc a podporu osobám za účelem sociálního začlenění nebo prevence sociálního vyloučení. Sociální služby vykazují všechny obecné charakteristiky, které jsou vlastní službám. I přes tuto skutečnost se však sociální služby a jejich trh liší od „klasických“ služeb a trhů. Podstata vyplývá z toho, jakou roli hrají sociální služby ve společnosti. Mezi odlišné charakteristiky sociálních služeb můžeme řadit např́íklad rozdíl ve financování, závislost na politických rozhodnutích, vazba na legislativu či etická a hodnotová dimenze. Tyto vztahy nám do jisté míry popisuje níže uvedená struktura CSR, která prakticky prezentuje provázanost jednotlivých aktérů a jejich vzájemné působení.

\footnotetext{
${ }^{12}$ Společenská odpovědnost firem [online] Byznys pro společnost. Fórum odpovědných firem, c2010.

${ }^{13}$ Společenská odpovědnost firem [online] BussinesInfo. Oficiální portál pro podnikání a export, c1997-2011.

${ }^{14}$ MOLEK, J. Marketing sociálních služeb. [online] Praha 2009.

${ }^{15}$ Zákon č. 108/2006 Sb., o sociálních službách.
} 


\section{Graf 2: Provázanost společenské odpovědnosti firem}

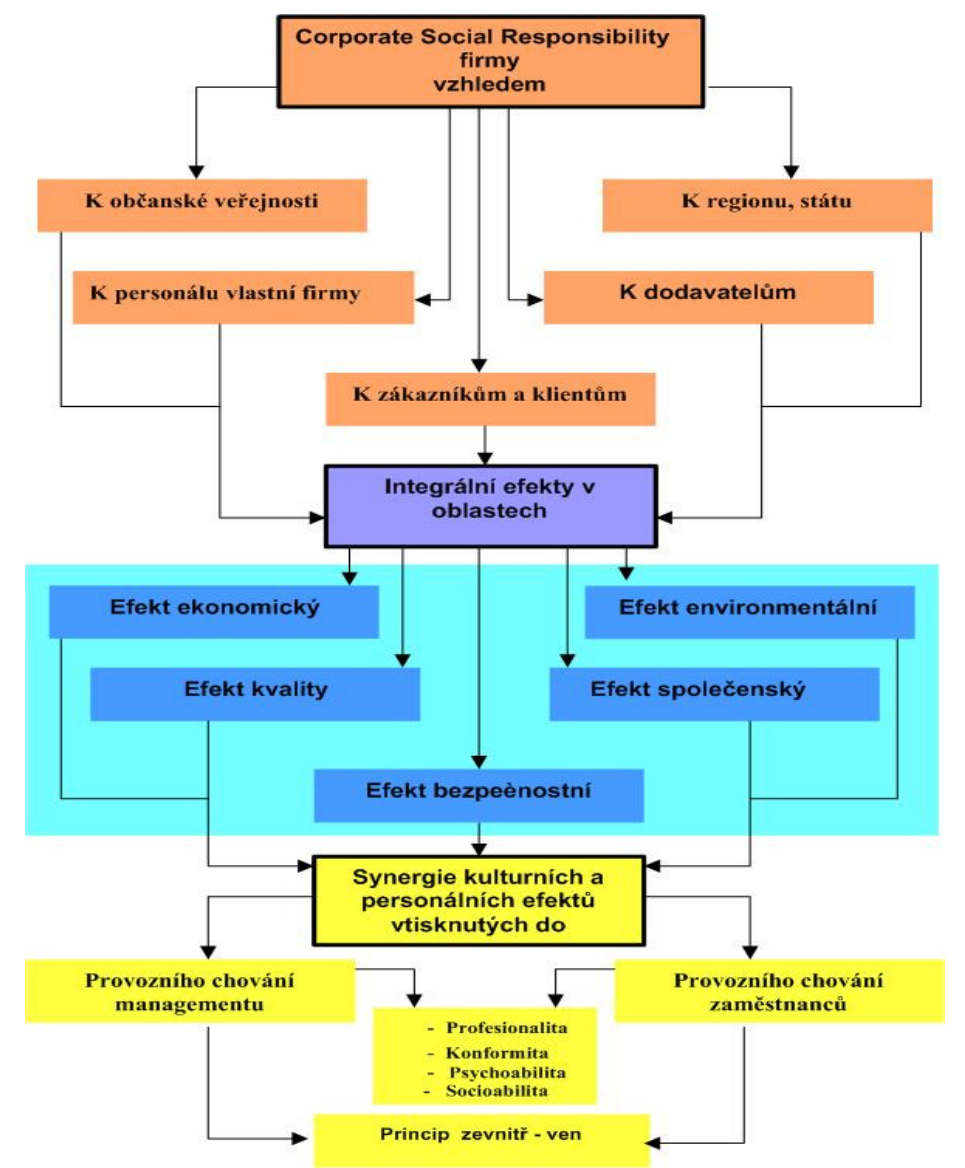

Zdroj: Kam až dosáhne CSR [online]. Vlastní cesta - poradenský portál, c2012 [cit. 11. 9. 2012]. Dostupné z: http://www.vlastnicesta.cz/akademie/kam-az-dosahne-corporate-social-responsibility-csr.

Přestože je tato provázanost zatím málo poznaným a pochopeným procesem, odhaluje však jak to vlastníci společensky odpovědné firmy se zákazníky, partnery, zaměstnanci a okolím myslí. Snaží se včlenit do procesů procházejících napříč celou firmou až do prostředí trhu, kde firma realizuje svoje podnikatelské aktivity. A to at' již v primární, sekundární nebo terciární sféře prostředí. Vyjadřují především svoji sociální misi, kterou je vnitřní dobrá vůle firmy přijmout nové a vyšší společenské závazky, které přidávají tzv. integrovanou hodnotu nejen produktům, ale i celé firmě a blízkému okolí. ${ }^{16}$

Sociální sféra CSR může být pro rozvoj sociálních služeb v regionu klíčová. Nabízí se zde různé formy dárcovství a investic do komunity ze strany firem, finanční př́spěvky, věcné dary, poskytnutí služeb, zapůjčení produktu nebo majetku apod., které by poskytovatelé sociálních služeb mohli využít. Aby systém donátorství místních podniků měl určitý řád a př́ínos pro komunitu, měl by vycházet z priorit a cílů zakotvených ve strategickém dokumentu obcí, který zpravidla bývá označován jako střednědobý (komunitní) plán rozvoje sociálních služeb v obci (kraji). Tento dokument je v současné době zpracován ve většině českých obcí III. stupně (obce s rožšířenou působnosti $1^{17}$ ) a v řadě obcí II. stupně (obce s pověřeným úřadem). Standardní obsah komunitního plánu zahrnuje v první části výsledky

\footnotetext{
${ }^{16}$ HORÁČEK, V. Kam až dosáhne Corporate Social Responsibility (CSR) [online]. Vlastní cesta - poradenský portál, c2012.

${ }^{17}$ Obecní úřady obcí s rozšiřrenou působností vykonávají některé oblasti působnosti navíc, a to vůči základnímu správnímu obvodu, ale zpravidla i pro další obce v okolí.
} 
provedených analýz a výzkumů jako je např́klad sociodemografická analýza prostředí (obce, případně regionu), která informuje o aktuálním věkovém složení obyvatel, přirozeném přírůstku a dalších trendech vývoje místní populace). Analýza existujících zdrojů zahrnuje především popis nejrůznějších existujících zdrojů (materiálních, lidských, finančních), mapování státních i nestátních poskytovatelů sociálních služeb a příspěvkových organizací obce. Druhá část, vystavěná na základě výsledků analýz existujících potřeb obyvatel v oblasti sociálních služeb, informuje o stanovených prioritách a hlavních cílech rozvoje služeb, rozpracovaných do jednotlivých opatření a konkrétních aktivit. Představitelé firem z plánu zjistí také rámcový časový harmonogram pro realizaci opatření a aktivit. Rovněž jsou zde uvedeny kontakty na konkrétní osoby i organizace, které hrají v plánování a posléze v implementaci plánu klíčovou roli. Poslední část dokumentu informuje o zásadách a pravidlech, které se týkají monitorování plnění jednotlivých kroků i celkové evaluace plánu. Ministerstvo práce a sociálních věcí České republiky označuje komunitní plán, jako výsledek vyjednávání mezi všemi účastníky procesu (především představiteli města, poskytovateli a uživateli služeb a části veřejnosti), který je realizován v rámci rozsáhlého partnerství v komunitě a který odpovídá podmínkám a potřebám místních občanů.

Z výše uvedených skutečností je zřejmé, že součástí tvorby střednědobých plánů je i rozsáhlá analýza a mapování potřeb uživatelů a poskytovatelů sociálních služeb, které se pak ve stanovení priorit a opatření př́ímo odráží. Reflexí této skutečnosti si pak firmy mohou být jisty, že pokud navrhnou model podpůrné strategie zaměřený na oblasti uvedené ve střednědobém plánu sociálních služeb, budou jejich investice použity na pomoc těm sociálním skupinám, které ji opravdu potřebují. Komunikace s koordinátory střednědobého plánování rozvoje sociálních služeb dává donátorům záruku, že jejich finanční prostředky či jiná forma podpory budou vynaloženy účelně a efektivně. Možnosti, které se partnerstvím soukromého a veřejného sektoru v rámci CSR rozkrývají, však nejsou stále dostatečně reflektovány a využívány. Jako příklad uved’me rozsáhlý aktuální výzkum střednědobého plánování v Moravskoslezském kraji „Analýza střednědobých plánů rozvoje sociálních služeb ve vztahu k potřebnosti, rozvoji a kvalitě sociálních služeb a jejich financování v Moravskoslezském kraji“18, který stanovil řadu faktorů a indikátorů k posouzení kvality plánování rozvoje sociálních služeb jako např. míra podílu naplnění krajského plánu v plánech jednotlivých obcí, kompetence pracovníků zapojených do procesu střednědobého plánování apod., avšak indikátor partnerství s firmami ze soukromého sektoru se zde v žádné podobě neobjevil (přestože jednou z částí je právě posouzení mapování zdrojů pro plánování i samotné sociální služby). Jedním z hlavních principů deklarovaných v procesu plánování sociálních služeb v obcích a krajích je princip partnerství, který je však stále uplatňován spíše ve smyslu několika partnerských neziskových organizací. Partnerství sektoru sociálních služeb se soukromým sektorem na úrovni tvorby a implementace střednědobých plánů nabízí řadu benefitů pro obě strany. Konkrétními benefity, kromě přímé finanční podpory, tedy získání hmotného zdroje pro sociální služby na straně jedné a důkazu deklarované filantropie na straně druhé, mohou být následovné: Na straně firmy je možnost proniknout do povědomí občanů lokality formou přímé prezentace na veřejných setkáních, organizovaných v rámci komunitního plánování - př́íkladem mohou být dny či veletrhy sociálních služeb, kulaté stoly, semináře a prezentace zaměřené na oblast sociálních služeb a určené pro občany obce (regionu), které bývají konány pravidelně. Část veřejnosti je na cyklické opakování veřejných aktivit zvyklá, proto opakovaná přímá prezentace firmy společně s prezentací donátorství na

\footnotetext{
${ }^{18}$ KOL. AUTORŮ. Analýza střednédobých plánů rozvoje sociálních služeb ve vztahu $k$ potřebnosti, rozvoji a kvalitě sociálních služeb a jejich financování v Moravskoslezském kraji. Olomouc, Ostrava: Sociotrendy, KÚ v Ostravě, 2012.
} 
webových stránkách komunitního plánování mohou přispět k propagaci cílů firmy v lokalitě. Profit na straně soukromých podniků může být i neprrímý, nabízí se např́ílad účast na dnech otevřených dveř́i v organizacích poskytujících sociální služby, účast vybraných zaměstnanců firmy na práci pracovních skupin, navázání osobních kontaktů a získání možnosti konzultací s odborníky na sociální oblast, kteří jsou v procesu plánování sociálních služeb zainteresováni apod. Z druhé perspektivy je zde možnost podpory samotného procesu střednědobého plánování v obci (majitelé a zaměstnanci firem mohou být členy politických stran či dokonce zastupitelstva měst, které o střednědobém plánu rozhodují). $\mathrm{Na}$ straně poskytovatelů sociálních služeb je profit nejen v získání finančních příspěvků a dotací, ale může jít např́íklad o patronaci určitého programu nebo projektu, získání dobrovolníků z řad zaměstnanců firmy, zapůjčení expertů pro řešení složitých úkolů, vytvoření matchingového fondu a ještě mnoho dalších možností. Partner z řad prosperujících firem může být dobrou příležitostí jak překonat rizika a ohrožení plynoucí z nedostatečných materiálních i jiných prostředků.

\section{Závěr}

Koncept společenské odpovědnosti firem vybízí firmy k aktivitě, která preferuje propracovanou dárcovskou strategii orientovanou zpravidla na podporu celé konkrétní komunity spíše než jednorázovou (a chaotickou) podporu nesourodých sociálních projektů. Cílem je širší podpora komunity resp. občanů žijících v lokalitě, rozvoj zdravého životního stylu a prostředí, podpora aktivizačních činností, které pomáhají návratu k „normálnímu životu“ u různých znevýhodněných sociálních skupin jako jsou lidé zdravotně postižení či osoby se specifickými sociálními problémy. Firmy, které se hlásí k CSR, mají svou účastí $\mathrm{v}$ procesu tvorby a implementace střednědobých (komunitních) plánů možnost př́imo přispívat $\mathrm{k}$ hlavnímu cíli rozvoje sociálních služeb, tedy $\mathrm{k}$ vytvoření efektivního modelu sociálních služeb na místní a regionální úrovni, který zajistí oprávněné potřeby klientů sociálních služeb a občanů určité lokality. Pokud firmy přizvou k realizaci své sociální odpovědnosti aktéry činné v komunitním resp. střednědobém plánování rozvoje sociálních služeb v obci (regionu) a druhá strana, tedy především obce a poskytovatelé sociálních služeb, si uvědomí, že partnerství se soukromým sektorem jim nabízí zdroje, které v současnosti mnohdy chybí, může dojít $\mathrm{k}$ vytvoření komplexního systému podpory a benefitů pro obě strany - sektor firem i sociálních služeb.

\section{Literatura:}

[1] AIDUKAI, J. Old welfare state theories and new welfare regimes in Eastern Europe: Challenges and implications. [online] In Communist and Post-Communist Studies, issue 1, volume 42, 2009, pages 29-39, Institute for Social Research, Vilnius, Lithuania. [cit. 15. 9. 2012]. Dostupné z: http://dx.doi.org/10.1016/j.postcomstud.2009.02.004.

[2] Corporate Social Responsibility. [online] [cit. 11. 9. 2012]. Dostupné z: http://www.wbcsd.org/work-program/business-role/previous-work/corporate-socialresponsibility.aspx.

[3] KOL. AUTORŮ. Analýza střednědobých plánů rozvoje sociálních služeb ve vztahu k potřebnosti, rozvoji a kvalitě sociálních služeb a jejich financování v Moravskoslezském kraji. Olomouc, Ostrava: Sociotrendy, KÚ v Ostravě, 2012, s. 176. ISBN 978-80904888-4-7.

[4] KREBS, V. a kol. Sociální politika. 4. vyd. Praha: ASPI, 2007. ISBN 978-80-7357-2761. 
[5] KULDOVÁ, L. Společenská odpovědnost firem. Etické podnikání a sociální odpovědnost v praxi. 1. vyd. Plzeň: OPS, 2010. 193 s. ISBN 978-80-87269-12-1.

[6] KUNZ, V. Společenská odpovědnost firem. 1. vyd. Praha: Grada, 2012. 208 s. ISBN 97880-247-3983-0.

[7] MICHALÍK, J. Smluvní vztahy v sociálních službách. 1.vyd. Olomouc: VCIZP, 2008, s. 32-33. ISBN 80-903658-1-7.

[8] MOLEK, J. Marketing sociálních služeb. [online] Praha: VUPSV, 2009. [cit. 15. 9. 2012]. Dostupné na: http://praha.vupsv.cz/Fulltext/vz_290.pdf.

[9] POTU゚ČEK, M. Křižovatky české sociální reformy. Praha: SLON, 1999, 317 s. ISBN 8085850-70-2.

[10]PRU゚ŠA, L. Sociální služby - srovnání ČR a EU, Praha: Centrum sociálních služeb, 2008, s. 60. Bez ISBN.

[11]Zákon ze dne 14. března 2006, č. 108 Sb., o sociálních službách. [online] [cit. 5. 9. 2012]. Dostupné na: http://www.mpsv.cz/files/clanky/7372/108_2006_Sb.pdf.

[12] Společenská odpovědnost firem [online] Byznys pro společnost. Fórum odpovědných firem, c2010 [cit. 15. 10. 2011]. Dostupné z: < http://www.byznysprospolecnost.cz/>.

[13] Společenská odpovědnost firem [online] Bussines Info. Oficiální portál pro podnikání a export, c1997-2011 [cit. 15. 10. 2011]. Dostupné z: < http://www.businessinfo.cz/cz/clanek/podnikatelske-prostredi/spolecenska-odpovednostfirem pruvodce/1001234/47816/>.

\section{JEL M14, R11}

\section{Ing. Lucie Kamrádová, Mgr. Jana Žáčková}

Ústav veřejné správy a regionální politiky

Fakulta veřejných politik

Slezská univerzita v Opavě

Hradecká 17, Opava

lucie.kamradova@fvp.slu.cz

jana.zackova@fvp.slu.cz 